\title{
Evaluation of Fuel Diversity in Solid Oxide Fuel Cell System
}

\author{
Amirpiran Amiri ${ }^{+, *}, 1$, Shi Tang ${ }^{+, 2}$, Robert Steinberger-Wilckens ${ }^{3}$, Moses O. Tadé ${ }^{4}$ \\ ${ }^{1}$ European Bioenergy Research Institute (EBRI), School of Engineering and Applied Science, Aston University, \\ Birmingham, B4 7ET, United Kingdom \\ ${ }^{2}$ Hubei Key Laboratory of Mechanical Transmission and Manufacturing Engineering, Wuhan University of Science and \\ Technology, Wuhan, 430081, PRC \\ ${ }^{3}$ School of Chemical Engineering, University of Birmingham, Edgbaston, Birmingham, B15 2 TT, UK \\ ${ }^{4}$ Department of Chemical Engineering, Curtin University, \\ Kent Street, Bentley, WA 6102, Australia \\ + Co-first Authors \\ *Corresponding Author: a.p.amiri@aston.ac.uk
}

\begin{abstract}
Operability of Solid Oxide Fuel Cell (SOFC) on numerous fuels has been widely counted as a leading advantage in literature. In a designed system, however, switching from a fuel to another is not practically a straightforward task as this causes several system performance issues in both dynamic and steady-state modes. In order to demonstrate the system fuel diversity capabilities, these consequences must be well-evaluated by quantifying the characteristic measures for numerous fuel cases and also potential combinations. From this viewpoint, the numerical predictive models play a critical role. This paper aims to investigate the performance of a SOFC system fed by various fuels using a demonstrated system level model. Process configuration and streams results of a real-life SOFC system rig published in literature are used to validate the model. The presented model is capable not only of capturing the system performance measures but also the SOFC internal variable distributions, allowing the multiscale study of fuel switching scenarios. The fuel change impacts on the system are simulated by considering various fuel sources, i.e., natural gas, biogas, and syngas. Moreover, applications of simulated fuel mixtures are assessed. The modelling results show significant concerns about fuel switching in a system in terms of variation of efficiencies, stack internal temperature and current density homogeneity, and environmental issues. Moreover, the results reveal opportunities for multi-fuel design to address the operation and application requirements such as optimisation of the anode off-gas recycling rate and the thermal-to-electrical ratio as well as the system specific greenhouse gases, i.e., $\mathrm{g}-\mathrm{CO}_{\mathrm{x}} / \mathrm{Wh}$ release.
\end{abstract}

Keywords: SOFC; system; model; Fuel flexibility; 


\section{Introduction}

Fuel cells have increasingly received attentions as a promising green technology for future highefficiency energy conversion. SOFCs, in particular, offer very interesting features such as operability on a wide spectrum of fuels owing to their high temperature operation [1-5]. Natural gas (NG), biogas (BG), syngas (SG) derived from biomass/coal gasification, and hydrogen are just a few examples of potential SOFC fuels. Renewable hydrogen sources, in particular, have increasingly received attention in recent years [6-8]. The integration of renewable hydrogen production process and fuel cell system is a practical solution for the issues relevant to hydrogen storage and transportation. The fuel reformation process can be carried out either internally or externally under technical and operational considerations associated to each. Moreover, the fuel reformation reaction pathways might be through various thermodynamically feasible mechanisms such as steam reforming, water-gas-shift reaction, partial oxidation, etc [9-10]. In spite of all promising opportunities mentioned, switching between numerous potential fuels and/or fuel reformation strategies is highly challenging due to the subsequent impacts on the system performance and control [11-12]. Analysis of the system behaviour operating on such wide fuel and fuel processing alternatives requires tens of scenarios to be examined [13]. In this view, without underestimating the crucial importance of experimental studies, the numerical models are more often preferred to study the possible scenarios particularly where both experimental and theoretical investigations are the alternative options.

The fuel cell focused modelling efforts can be classified based on the ultimate targets for which the numerical tool will be applied. Taking the model goal into account the models time and length scales are significantly wide [14]. The so-called "system" model, for instance, refers to those models which are purposefully developed to be used in synthesising, analysing, and optimising a fuel cell system (plant). In such model, therefore, the details of cell/stack are always simplified in order to keep the main focus on the system features such as the major unit operations interaction/integration. The fuel cell unit, therefore, is always approximated by a 0D or black-box model and further attention is paid to the balance of plant $(\mathrm{BoP})$. Whenever the fuel cell reactor itself becomes central in the mathematical modelling a "cell/stack" oriented model would be attained. This type of model mainly accounts for the cell/stack details including, but not limited to, internal distributed profiles (e.g., current, temperature, overpotentials, ohmic resistance, etc.), efficiency and more detailed microlevel concepts such as cell degradation. In such a model, other units in BoP and their mutual interaction with the fuel cell stack are extensively compromised or even completely ignored. 
Accordingly, the research outcomes based on an isolated single cell might not be directly generalised to the cells embedded in a multi-cell stack. Similarly, an isolated fuel cell stack unit may behave differently compared to when it is integrated with BoP units working interactively. Although the single scale focused model offers significant advantages, e.g., simpler equation sets and faster computation, a practical fuel cell system model must ideally capture the main spatiotemporal and the interactive scales involved through a computationally effective multiscale modelling framework. This is, particularly, of critical importance in assessing various fuels and fuel reformation pathways where the fuel pre- and post-processing component impacts on the fuel cell stack and vice versa must not be compromised.

Fuel diversity assessment requires a multiscale system level model. In a previous study [15] the emphasis was placed on the stack-BoP interactions as well as the stacking related matters, such as manifold malfunction, to capture the stack internal distribution profiles and gradients. Even though a parametric analysis at system level was presented, estimation of flowsheet streams data and interaction of BoP components were out of scope. This is a lack as the process design and process optimisation, at both basic and detailed design stages, largely rely on the flowsheet mass and energy balance data. This paper aims to cover the mentioned modelling gap and then analyse the fuel diversity relevant concerns at system level with special attention to the stack internal profiles by using a detailed stack model embedded in the BoP. To meet these a SOFC system test rig presented in [16] was simulated first for model upgrading and validation specifically in predicting the system level performance. Subsequently, the impact of fuel source variation on the system and SOFC stack performances will be estimated and discussed.

\section{Modelling outline and model validation}

The modelling platform developed by the authors [17] is used for simulation of SOFC systems in external reforming operation to be able to use test rig results presented in [16] which uses external reformer. Through the mentioned modelling platform, SOFC systems fed by a wide spectrum of fuels and with various external reformation strategies, including Steam Reforming, Partial Oxidation Reforming, Authothermal Reforming, and Water-Gas Shift Reactions, can be simulated. These simulations are readily possible by selecting fuels species from the Aspen material directory, and using appropriate in-built reactors run by the suitable reformation(s) kinetics. The user defined SOFC stack introduced in [17] can be linked to BoP with an external fuel reformation sub-plant regardless of the fuel type. This feature provides the flexibility and easiness for testing diverse fuels, and reforming route variation scenarios, cost effectively and within a reasonable time. The data exchange 
between the SOFC stack and other BoP components is bidirectional by recycling the exhaust gases from stack outlet to the system upstream forming the recirculation loops in the process flowsheet. The simulation and verification of SOFC flowsheet data is conducted in this work to prove the model fidelity and reliability.

\section{System Performance Measures}

In order to capture the influence of the fuel variation on the stack and system performance, several performance indicators are taken into account. Variables including the system combined efficiency ( $\left.\eta^{\text {System }}\right)$, stack current density $(i)$, stack average temperature ( $\left.\bar{T}^{\text {Stack }}\right)$, temperature differences between the stack input and output $(\Delta \mathrm{T})$, and system exhaust temperature ( $\left.\mathrm{T}_{\text {Exhaust }}\right)$ are evaluated. System energy input rate $\left(P_{i n}^{\text {System }}\right)$ via chemical fuel is considered to be constant as $90 \mathrm{~W}$, regardless of the fuel type. Accordingly, given LHV values for each fuel, the corresponding fuels molar flowrates $\left(\mathrm{F}_{\text {fuel }}\right)$ are estimated by using Equation 1;

$$
\mathrm{F}_{\text {fuel }}=\frac{P_{\text {in }}^{\text {System }}}{L H V_{\text {fuel }}}
$$

Furthermore, the stack electrical efficiency is calculated as (Equation 2);

$$
\eta_{e l}=\frac{P_{n e t}}{P_{i n}^{S y s t e m}}
$$

The net system power, $P_{n e t}$, is estimated based on the electric power generation and consumption within the system (Equation 3):

$$
P_{n e t}=(V . I)^{\text {Stack }}-P^{\text {Blower }}
$$

where

$$
P^{\text {Blower }}=F_{\alpha} C_{p} T_{0}\left[\frac{\left(\frac{p_{\text {out }}}{p_{0}}\right)^{\frac{k-1}{k}}-1}{\eta_{\text {isen }}^{\text {Blower }}}\right]
$$

The available thermal energy in the system $\left(\mathrm{E}_{\mathrm{th}}\right)$ is estimated as the system exhaust gas enthalpy that can be used for heating purposes or be converted to mechanical work. The portion of the exhaust heat that can be recovered may vary from $38 \% \sim 70 \%$ [18-20], depending on the utilisation process design. Since heat recovery strategies are not among the focus of this work, a constant heat recovery coefficient $(\beta=0.6)$ is assumed in all of the case studies for the sake of consistency. The system thermal efficiency for each case study is defined as the ratio of recoverable thermal energy to the system input energy. 
$\eta_{t h}=\frac{\beta E_{t h}}{P_{i n}^{\text {System }}}$

Total (combined) system efficiency is calculated as:

$\eta^{\text {System }}=\eta_{e l}+\eta_{t h}$

For the stack distributed variables, a deviation factor is calculated based on the Equation 7:

$D(\%)=\frac{n \cdot M-\sum_{j} M_{j}}{\sum_{j} M_{j}} \times 100$

where $\mathrm{M}$ is the stack variable $(=\mathrm{i}, \mathrm{T}, \Delta \mathrm{T}), \mathrm{n}$ stands for number of fuels $(=6)$, and $\mathrm{j}$ is fuel type $(\mathrm{j}=$ NG, BG, SG, SF\#1, SF\#2, SF\#3)

\section{Experimental rig simulation}

A SOFC system test rig with external fuel pre-processing unit has been demonstrated by Powell et al. [16]. The presented process consists of major SOFC system components including the steam reformer, recuperators, and blowers for anode and cathode gas streams, exhaust condenser, and mass flow controllers all integrated with a multilayer SOFC stack. The demonstrated system attained net power output of $1650-2150 \mathrm{~W}$ with a maximum net electrical efficiency of 0.60 calculated based on LHV. The test rig had no afterburner. Sulphur free $\mathrm{CH}_{4}$ (purity $>99.9 \%$ ) was utilised as the fuel. The external fuel reformer, however, was fed with a mixture of fresh fuel mixed with a part of anode exhaust gases recycled at a rate of $85 \%$. The recycle rate is defined as the percentage of anode outlet flow that is used in the reformer rather than being vented. The reformate properties are a strong function of reformer operating conditions including reformer temperature, pressure, and residence time, and the recycle ratio as well as the composition of fresh feed, etc. Given the operating conditions in [16], the reformate fed into the SOFC stack mainly consisted of $\mathrm{CO}, \mathrm{CO}_{2}, \mathrm{H}_{2}, \mathrm{H}_{2} \mathrm{O}$, and possibly a very small portion of unreacted $\mathrm{CH}_{4}$. Therefore, internal reforming can reasonably be ignored. Since the fuel reforming process occurs adiabatically in the experimental setup, the temperature of reformate is lower than the reformer feed due to the endothermic nature of reactions taking place. Moreover, the anode gas was passed through a blower where the elevated temperature would cause technical problems. Therefore, the reformate was cooled down to $145{ }^{\circ} \mathrm{C}$ before being pressurised in the blower. The cooling process was executed through the anode recuperator and partially via heat loss to the surrounding. Taking these concerns and domain specifications into 
account, the lab scale process, Figure 1A presented in [16] was simulated as can be seen in Figure $1 \mathrm{~B}$.

The system presented in [16] possesses an external fuel reformer and operates with a co-flow pattern for air and fuel inside cells. We used the same reforming and flow specifications to be able to compare the results for simulation validation. Since a co-flow pattern for the fuel and air flows in the cell channels was simulated, changes in y direction shown in Figure 1 were negligible. Moreover, the heat transfer between the cells/layers inside the stack and also between stack and environment was neglected. The former was because of the minor impact of cell-to-cell thermal impact within the four cell short stack $[15,21]$. The latter assumption was justifiable for a wellinsulated SOFC stack operating adiabatically in the system. Moreover, an even distribution of fuel and air between layers in the stack was assumed. Taking all of these assumptions into account, variations in stacking direction, $\mathrm{z}$, could be ignored and therefore the profiles were only captured in one dimension along the cell length, $\mathrm{x}$. The recycle ratio used in the simulations was 0.85 to be consistent with the practical test rig operating conditions [16].

As can be seen in Table 1 the simulated results were in reasonable agreement with the experimental data. The calculated electrical efficiency for the methane-fed system was about $62 \%$ which was well consistent with the experimental data in [16]. Note that no thermal efficiency was considered in the mentioned work hence the overall efficiency was estimated based on the electrical efficiency only. There is discrepancy between the model and experimental results for Stream 15, and hence 16. The reason is that while the air/fuel ration was $\sim 13.5$ in the test rig operation, it was adjusted at $\sim 21$ in the simulation to reasonably fit the temperatures. Therefore, the oxygen utilisation achieved through the model was lower than real one as is reflected in Stream 15/16. Moreover, the inconsistency between the model-based predicted and experimentally measured data for Stream 11 is because of data reporting basis, i.e., dry and wet basis. Since cooling process for Stream 10, reducing temperature from $200{ }^{\circ} \mathrm{C}$ to $25^{\circ} \mathrm{C}$ using a small size condenser is technically challenging, it seems that this has not been successfully achieved in the experiments [16], passing water mainly into Stream 11 rather than water drain steam $\left(\mathrm{H}_{2} \mathrm{O}\right.$ stream in Figure 1A). This, however, was not the case in the simulation where it is thermodynamically possible to remove water from tail gas at $25{ }^{\circ} \mathrm{C}$ leaving dry Stream 11.

\section{Process analysis results and discussion}

Heat generated from unreacted fuel combustion in an afterburner provides thermal energy for the system internal usage, such as gases preheating and the endothermic reformation process heat 
demands, and also heat for external uses, such as hot water preparation in residential applications. In this aspect, the afterburner is a very important component of the SOFC system to be simulated for a fuel assessment study. Since the process presented in [16] did not include the off-gas burner, the process flowsheet was modified, as shown in Figure 2, to include the burner in the thermal efficiency estimation, enabling a more comprehensive process analysis.

\section{Impact of fuel source}

The impact of fuel change on the system performance characteristics was analysed based on the model and parameters presented in Figure 2 and Table 2, respectively. There are further parameters that are not used in this work directly, but are used in the simulator equations and programming demonstrated in [17]. Three widely accepted fuels for SOFC, including NG, BG and coal SG, were used in the simulation. Moreover, three so-called "simulated fuel (SF)" mixtures generated by mixing of NG and SG gases were taken into account. In order to parametrically explore the SF features, the NG and SG fractions in SFs compositions were assumed as there is no specific standard composition available in the literature. The SF mixture properties were estimated by Aspen Plus using the inbuilt mixing rules. Fuel specifications are presented in Table 3 . The flowsheet stream results relevant to each fuel are presented in the Appendix.

The results presented in Table 4 reveal that the fuel type/source considerably influences the SOFC stack and system performance. With respect to the individual efficiency terms, seen in Equation 6, application of NG fuel results in a maximised electrical efficiency and minimised thermal efficiency compared to other fuels. Taking the endothermic NG reformation reaction into account, the higher electrical efficiency stems from the recycling of heat into the reformer and thus conversion of (waste) heat into chemical (fuel) energy that can then be converted into electricity. From this perspective, we would expect lower electrical efficiencies with higher hydrogen fuel content as heat recovery opportunity via fuel conversion is lesser. The NG-fed system overall efficiency is maximum compared against other fuels. In contrast, a system that operates on SG offers the lowest electric and highest thermal efficiencies because this is the only gas without $\mathrm{CH}_{4}$ content and thus does not benefit from waste heat recycling in the reformer. These observations are relevant to $\mathrm{H}_{2}$ and heat qualities in the stack inlet and the burner outlet, respectively. In order to compare the recoverable heat in the exhaust, the anode side flow rate must be taken into account in addition to the stream temperature. The anode flow rate is very high in the SG-fuelled case causing strongest cooling effect in anode feed, compared to other fuels and particularly NG. From the efficiency point 
of view, a BG-fed system stands in the middle of the list having electrical and thermal efficiencies reasonably balanced. While stack feed dilution reduces the generated current and hence causes the electrical efficiency reduction in the stack, its thermal efficiency is improved compared to the NGfed process.

Figure 3 captures current density and temperature profiles for the deployed fuels. Along the xaxis, current and temperature profile inhomogeneity are maximum and minimum for NG and SG fuels, respectively. Given equal stack inlet temperature for all fuels involved in this analysis, temperature growth due to the electrochemical reaction heat along the cell length varies considerably. The NG-fed cell shows the maximum temperature growth that can be explained based on the exothermic current generation reaction and hence the heat accumulation. Higher current comes at the cost of extreme temperature gradients that cause thermal stresses. All fuels offer average stack temperatures high enough to conduct the methane internal reforming process in case external reformation was not perfect. The temperature and current profile differences become more considerable towards the cell outlet. By switching the fuel from SG to NG, temperature and current density may vary up to $26 \mathrm{~K}$, and $1400 \mathrm{~A} / \mathrm{m}^{2}$, respectively, at the cell outlet. This shows that the design of the cooling system must be chosen differently for individual fuels.

The more homogenous the reaction and temperature profiles, the better cell and stack performance will be in terms of lifetime. Therefore, internal gradients are among the key indicators that must be estimated to evaluate the impacts of fuels switching. For the comparison purpose the deviation factors - defined as the deviation from an overall average value that is achieved across the studied fuels - for stack variables fuelled by different fuels were calculated based on Equation 7 and presented in Figure 4. While positive deviations for current and temperature are desirable, as they show that the fuel change enhances the electrochemical reaction and hence the cell electric performance, the negative deviation for $\Delta \mathrm{T}$ is more desirable as it indicates lower thermal inhomogeneity inside the stack. Since temperature profiles captured in this study are approximately linear, we use $\Delta \mathrm{T}^{\text {Stack }} / \mathrm{L}^{\text {cell }}$ and $\mathrm{dT} / \mathrm{dx}$ as exchangeable alternatives in this paper.

The deviation graphs show that the system fuelled by SF\#2 can be counted as a basis to compare other fuels with as it performs very close to the average. The system fuelled by NG, in contrast, deviates significantly from average temperature and current values, also causes higher temperature inhomogeneity as the $\Delta \mathrm{T}$ deviation graph shows. On the other hand, when the system is operated on 
$\mathrm{SG}$ as fuel, a minimum $\Delta \mathrm{T}$ can be achieved at the price of a reduction in current generation. An anode outlet temperature reduction is observed that can be explained by a declining exothermic electrochemical reaction. However, this can be advantageous as heat can be recovered from unreacted fuel in the burner and result in higher thermal efficiency term as shown in Table 4. SOFC systems operated by using BG and simulated fuels behave between the extreme cases, i.e., a system fuelled by a mixture of NG and SG, offering substantial potential for fuel design to address internal homogeneities, in addition to the efficiency concerns presented in Table 4, through multivariable optimisation efforts.

Distributed voltage data for various fuels studied in this work are depicted in Figure 5. Note that all simulations are based on a constant operating voltage while local OCV and overpotentials are estimated using the local temperature and concentration conditions. As can be seen in Figure 5, application of NG as main fuel leads to the highest local OCV and overpotentials compared to the rest of fuels listed. In particular, the OCV profile for a stack fuelled by a reformate mixture from NG is considerably noticeable from the others. This result indicates the crucial importance of the reformate properties, and hence the fuel source, in stack voltage characteristics. The SG-fed system shows minimum local values of OCV and losses. While the cathode activation loss trends remain almost the same for all fuels, declining at the same rate along the cell length, the reduction rate of the anode activation loss is more considerable for NG compared to that of the other fuels. The difference between anode activation losses of various fuels becomes less at points close to the cell outlet.

\section{Thermal-to-electrical ratio (TER)}

An important performance indicator for adjusting the energy supply based on the energy demand is the thermal-to-electrical ratio (TER) at the system level. TER demand for residential building applications may range from 0.35 to 2.1. The range of achievable TER in SOFC based on combined heat and power (CHP) system designs may vary typically from 0.5 to $2.0[18,24]$. The concurrent system TER and efficiency changes analysis against the fuel choice is presented in Figure 6 . Achieving the higher TER performance is reasonably feasible by using appropriate SFs, but at the cost of an overall efficiency reduction, showing that the fuels (NG and SG) mixing is promising to meet the TER targets for various applications. The overall system efficiency fluctuates about $13 \%$ when the NG fraction in the SF varies from 0 to 1 while it also strongly affects TER in a relatively wide spectrum from 0.4 to 1.6 . System optimisation is a multi-objective optimisation, considering the controversial TER and efficiency behaviours. 


\section{System $\mathrm{CO}_{\mathrm{x}}$ analysis}

The $\mathrm{CO}_{\mathrm{x}}$ released from the fuel cell system is also a critical measure in assessing the applicability of various potentials fuels. While the overall specific $\mathrm{CO}_{\mathrm{x}}$ release per unit power $\left(\mathrm{g}-\mathrm{CO}_{\mathrm{x}} / \mathrm{Wh}\right)$, as the most common indicator, is estimated, $\mathrm{CO}$, and $\mathrm{CO}_{2}$ fractions are also calculated at two points of the process, the stack anode outlet and the system exhaust. From the process design and analysis viewpoint, the chosen process points are logical bottlenecks to be checked. Indeed, stack outlet flow data help in designing appropriate strategies for the anode and cathode off-gas post-processing within the system itself, such as estimating the portion of stack exhaust gasses to be either burnt or recycled. Moreover, system overall emission evaluation and control can be undertaken by using the system exhaust composition information from the flowsheet.

As can be seen in Figure 7, the simulation results indicate that residual gases from NG and SG fuelled systems are, respectively, the cleanest and dirtiest outlets in terms of $\mathrm{CO}_{2}$ content. The $\mathrm{CO}$ share in the system exhaust is negligible mainly because of almost complete conversion of $\mathrm{CO}$ to $\mathrm{CO}_{2}$ in the burner. Moreover, this stream is significantly diluted by the added cathode off-gas inserted to the burner. However, this does not affect the associate $\mathrm{g}-\mathrm{CO}_{\mathrm{x}} / \mathrm{Wh}$ for fuels. The simulation results show about $250 \mathrm{~g}-\mathrm{CO}_{\mathrm{x}} / \mathrm{kWh}$ for a system operated by using NG which is in agreement with technical literature [25].

For all examined fuels, the stack exhaust consists of a considerable amount of $\mathrm{CO}$ and hence reveals the importance of internal water gas shift reaction and $\mathrm{CO}$ oxidation, both using $\mathrm{CO}$ as fuel. Nevertheless, a high rate of anode off-gas recycling may not be recommended in cases with high $\mathrm{CO}_{2} / \mathrm{CO}$ ratio, to minimise the carbon formation risk in the stack caused by a high $\mathrm{CO}_{2}$ partial pressure. While the mentioned ratio is about 0.11 for $\mathrm{NG}$, it is about 0.29 and 0.67 for $\mathrm{BG}$ and $\mathrm{SG}$, respectively. This observation reveals the challenges relevant to anode off-gas recycling in a fuel changing scenario. As Figure 7 shows, the simulated fuels sound promising for handling a $\mathrm{CO}_{2} / \mathrm{CO}$ ratio adjustment.

\section{Conclusions}

Applicability of various fuels and the feasibility of various fuel processing methods have been extensively emphasised as crucial advantages of SOFC in the literature. In spite of this, fuel altering in a SOFC system might result in problematic operational and technical consequences. Given that adaption of system design and $\mathrm{BoP}$ component specifications for a new fuel is hardly feasible, or even impossible in some cases, system tolerance for fuel switching scenarios must be evaluated first. 
Evaluation of the fuel processing and fuel source alterations can require tens of scenarios to be tested. Numerical tools and particularly commercial process flowsheeting platforms that are capable to take stack details into account are critically required to minimise the cost and time of such numerous test series. Application of a user-defined SOFC stack in the Aspen Plus environment was demonstrated in this paper to assess the fuel change challenges and opportunities in a typical SOFC plant. The SOFC plant was simulated based on a real-life test set-up for validation purposes. The process flowsheet was modified to include an afterburner unit for fuel post-processing for meeting the heat generation target. It was shown that fuel variation may significantly affect the uniformity of stack internal profiles and system overall performance metrics. Moreover, the modelling observations give the insight for system-wide multi-objective optimisation opportunities through fuel selection and design. Results show that NG is a suitable fuel for a system that is mainly designed for electricity production applications while heat generation is of lower importance. On the other hand, BG could be suggested as promising fuel for balanced cogeneration of electric and thermal energies to meet the TER requirement in various applications. In contrast, a SOFC-based system fuelled by SG offers high thermal output at the cost of reduced electrical output compared to NG and BG-fed systems. It also moderates the thermal stresses inside the stack. Since all of the desirable specifications are not available in a single fuel, a multi-variable-multi-objective optimisation is needed. Fuel blending is an option to attain a specification of interest in a fuel mixture while its composition is designed/optimised.

\section{Appendix}

The system stream results for the process (Figure 2) fed by the studied fuels, i.e., NG, BG, SG, SF\#1, SF\#1 SF\#1, are presented in Tables A1-A6, respectively

\section{Acknowledgements}

The authors acknowledge the financial supports by Hubei Provincial Natural Science Foundation of China (Grant No. 2018CFB143) for this research 


\section{References:}

[1] Yi Y, Rao AD, Brouwer J, Samuelsen GS. Fuel flexibility study of an integrated $25 \mathrm{~kW}$ SOFC reformer system . Journal of Power Sources. 2005;144:67-76.

[2] Yoon SP, Kim HJ, Park BT, Nam SW, Han J, Lim TH, Hong SA. Mixed-fuels fuel cell running on methane-air mixture. Journal of Fuel Cell Science \& Technology. 2006;3:836.

[3] Douvartzides SL, Coutelieris FA, Demin AK, Tsiakaras PE. Fuel options for solid oxide fuel cells: A thermodynamic analysis. AICHE Journal. 2010;49:248-57.

[4] Ni M. Modeling of SOFC running on partially pre-reformed gas mixture. International Journal of Hydrogen Energy. 2012;37:1731-45.

[5] Dokmaingam P, Irvine JTS, Assabumrungrat S, Charojrochkul S, Laosiripojana N. Modeling of IT-SOFC with indirect internal reforming operation fueled by methane: Effect of oxygen adding as autothermal reforming. International Journal of Hydrogen Energy. 2010;35:13271-9.

[6] Schoenung SM, Keller JO. Commercial potential for renewable hydrogen in California. International Journal of Hydrogen Energy. 2017;42.

[7] Hotza D, Costa JCDD. Fuel cells development and hydrogen production from renewable resources in Brazil. International Journal of Hydrogen Energy. 2008;33:4915-49352.

[8] Lin J, Trabold TA, Walluk MR, Smith DF. Bio-fuel reformation for solid oxide fuel cell applications. Part 3: Biodiesel-diesel blends. International Journal of Hydrogen Energy. 2014;39:196-208.

[9] Lee PH, Sang SH. Numerical simulation on non-catalytic thermal process of methane reformation for hydrogen productions. International Journal of Hydrogen Energy. 2017;42.

[10] Thanomjit C, Patcharavorachot Y, Ponpesh P, Arpornwichanop A. Thermodynamic analysis of solid oxide fuel cell system using different ethanol reforming processes. International Journal of Hydrogen Energy. 2015;40:6950-8.

[11] Harun NF, Tucker D, Adams TA. Open Loop and Closed Loop Performance of Solid Oxide Fuel Cell Turbine Hybrid Systems During Fuel Composition Changes. ASME Turbo Expo, Turbine Technical Conference and Exposition 2017. p. V003T06A23.

[12] Harun NF, Tucker D, Ii TAA. Technical challenges in operating an SOFC in fuel flexible gas turbine hybrid systems: Coupling effects of cathode air mass flow. Applied Energy. 2017;190:852-67.

[13] Ii TAA, Nease J, Tucker D, Barton PI. Energy Conversion with Solid Oxide Fuel Cell Systems: A Review of Concepts and Outlooks for the Short- and Long-Term. Industrial \& Engineering Chemistry Research. 2013;52:3089-111. 
[14] Wang K, Hissel D, Péra MC, Steiner N, Marra D, Sorrentino M, et al. A Review on solid oxide fuel cell models. International Journal of Hydrogen Energy. 2011;36:7212-28.

[15] Amiri A, Vijay P, Tadé MO, Ahmed K, Ingram GD, Pareek V, Utikar R. Solid oxide fuel cell reactor analysis and optimisation through a novel multi-scale modelling strategy. Computers \& Chemical Engineering. 2015;78:10-23.

[16] Powell M, Meinhardt K, Sprenkle V, Chick L, Mcvay G. Demonstration of a highly efficient solid oxide fuel cell power system using adiabatic steam reforming and anode gas recirculation. Journal of Power Sources. 2012;205:377-84.

[17] Amiri A, Vijay P, Tadé MO, Ahmed K, Ingram GD, Pareek V, Utikar R. Planar SOFC system modelling and simulation including a 3D stack module. International Journal of Hydrogen Energy. 2016;41:2919-30.

[18] Braun RJ, Klein SA, Reindl DT. Evaluation of system configurations for solid oxide fuel cell-based micro-combined heat and power generators in residential applications. Journal of Power Sources. 2006;158:1290-305.

[19] Nehrir M. H, Wang C. Modeling and Control of Fuel Cells: Distributed Generation Applications. Wiley-IEEE Press. 2009.

[20] Iv EJN, Sleiti AK. Potential of SOFC-CHP systems for energy-efficient commercial buildings. Energy \& Buildings. 2013;61:153-60.

[21] Nikooyeh K, Jeje AA, Hill JM. 3D modeling of anode-supported planar SOFC with internal reforming of methane. Journal of Power Sources. 2007;171:601-9.

[22] King County Fuel Cell Demonstration Project, Technical Project Report, King County Department of Natural Resources. 2009.

[23] Wabash River Coal Gasification Repowering Project, Wabash River Energy Ltd., 2000, 4-80.

[24] Shearing P, Brandon N. Solid Oxide Fuel Cells: From Materials to System Modeling. RSC Energy and Environment Series, 2013.

[25] Natural Gas-Fuelled Distributed Generation Solid Oxide Fuel Cell Systems, Projection of Performance and Cost of Electricity, Report Number: R102 04 2009/1, US Department of Energy, National Energy Technology Laboratory, and RDS. 2009.

[26] Zhang L, Li X, Jiang J, Li S, Yang J, Li J. Dynamic modeling and analysis of a 5-kW solid oxide fuel cell system from the perspectives of cooperative control of thermal safety and high efficiency. International Journal Of Hydrogen Energy. 2015;40:456-76. 


\section{Nomenclature}

\begin{tabular}{|c|c|}
\hline $\mathrm{C}_{\mathrm{p}}$ & Specific heat $\left(\mathrm{J} \mathrm{mol}^{-1} \mathrm{~K}^{-1}\right)$ \\
\hline $\mathrm{D}$ & Deviation factor $(\%)$ \\
\hline $\mathrm{E}$ & Energy (W) \\
\hline $\mathrm{F}$ & Molar flow rate $\left(\mathrm{mol} \mathrm{s}^{-1}\right)$ \\
\hline I & Current (A) \\
\hline $\mathrm{i}$ & Current density $\left(\mathrm{A} \mathrm{m}^{-2}\right)$ \\
\hline $\mathrm{j}$ & Fuel type (= NG, BG, SG, SF\#1, SF\#2, SF\#3) \\
\hline LHV & Lower heating value $\left(\mathrm{J} \mathrm{mol}^{-1}\right)$ \\
\hline $\mathrm{L}$ & Length (m) \\
\hline M & Stack variable $(=\mathrm{i}, \mathrm{T}, \Delta \mathrm{T})$ \\
\hline $\mathrm{n}$ & Number of fuel types $(=6)$ \\
\hline $\mathrm{p}$ & Pressure $(\mathrm{Pa})$ \\
\hline $\mathrm{P}$ & Power (W) \\
\hline$\overline{\mathrm{T}}$ & Average temperature $(\mathrm{K})$ \\
\hline$\Delta \mathrm{T}$ & Temperature differences $(\mathrm{K})$ \\
\hline $\mathrm{V}$ & Operating voltage (V) \\
\hline $\mathrm{x}$ & Location along the flow direction (m) \\
\hline
\end{tabular}

Greek Letters

$\kappa$

Specific heating ratio $(=1.4)^{[26]}$

$\beta$

Heat recovery coefficient

$\eta$

Efficiency (\%)

Sub-/Superscripts

a

Air

blower

Air blower 
el

insen

in

out

th

0

Acronyms

$\mathrm{BoP}$

PEN

OCV

SOFC

TER

NG

BG

SG

SF
Electrical

Isentropic

inlet

Outlet

Thermal

Ambient

Balance of Plant

Positive Electrode-Electrolyte-Negative Electrode Open Circuit Voltage

Solid Oxide Fuel Cell

Thermal to Electrical Ratio

Natural Gas

Biogas

Syngas

Simulated Fuel 
Table 1: The model-based process streams (Figure 1) specifications results (M) compared to the experimental (E) results [16].

\begin{tabular}{|c|c|c|c|c|c|c|c|c|c|c|c|c|c|c|c|c|}
\hline \multirow{2}{*}{$\begin{array}{l}\mathscr{\mathscr { E }} \\
\stackrel{\Xi}{0} \\
\stackrel{\Xi}{\Xi}\end{array}$} & \multicolumn{2}{|c|}{$\begin{array}{l}\text { Temperature } \\
\text { (K) }\end{array}$} & \multicolumn{2}{|c|}{$\begin{array}{c}\mathrm{CO}_{2} \\
(\% \mathrm{~mol})\end{array}$} & \multicolumn{2}{|c|}{$\begin{array}{c}\mathrm{CO} \\
(\% \mathrm{~mol})\end{array}$} & \multicolumn{2}{|c|}{$\begin{array}{c}\mathrm{CH}_{4} \\
(\% \mathrm{~mol})\end{array}$} & \multicolumn{2}{|c|}{$\begin{array}{c}\mathrm{H}_{2} \\
(\% \mathrm{~mol})\end{array}$} & \multicolumn{2}{|c|}{$\begin{array}{c}\mathrm{H}_{2} \mathrm{O} \\
(\% \mathrm{~mol})\end{array}$} & \multicolumn{2}{|c|}{$\begin{array}{c}\mathrm{N}_{2} \\
(\% \mathrm{~mol})\end{array}$} & \multicolumn{2}{|c|}{$\begin{array}{c}\mathrm{O}_{2} \\
(\% \mathrm{~mol})\end{array}$} \\
\hline & $\mathbf{E}$ & 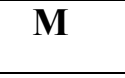 & $\mathbf{E}$ & $\mathbf{M}$ & $\mathbf{E}$ & $\mathbf{M}$ & $\mathbf{E}$ & $\mathbf{M}$ & $\mathbf{E}$ & $\mathbf{M}$ & $\mathbf{E}$ & M & $\mathbf{E}$ & $\mathbf{M}$ & $\mathbf{E}$ & M \\
\hline 1 & 2 & 298 & & & & & 100 & 100 & 0 & 00 & & & & 00 & 0.0 & 0.0 \\
\hline 2 & 103 & & & 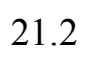 & & 3.2 & 0.0 & & 5.6 & 11.9 & 0 & 57.3 & 5 & 5.4 & .0 & .0 \\
\hline 3 & 971 & & 27.0 & 19 & & 3.0 & 6.1 & 48 & 5 & 11.0 & 53.0 & 55.9 & 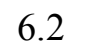 & 5.8 & .0 & .0 \\
\hline 4 & 799 & 003 & 28.0 & 21 & 3.1 & 3.3 & 1.8 & 0.9 & .2 & 23.8 & 42.0 & 45 & 5.7 & 5.4 & .0 & .0 \\
\hline 5 & 473 & & 28.0 & 21.2 & 3.1 & J.J & 1.8 & 0.9 & 9.2 & 3.8 & 42.0 & TU & 7 & 5.4 & 0 & .0 \\
\hline 6 & 41 & & 28 & 21 & 3 & 3.3 & 1.8 & 0.9 & 19.2 & 23.8 & 42.0 & 45.5 & .7 & 5.4 & 0.0 & 0.0 \\
\hline 7 & 43 & & 28 & 21 & 3.1 & 3.3 & 1.8 & 0.9 & 19.2 & 23.8 & 42.0 & 45.5 & .7 & 5.4 & 0.0 & 0.0 \\
\hline 8 & 820 & & 28.0 & 21.2 & 3.1 & 3.3 & 1.8 & 0.9 & 19.2 & 23.8 & 42.0 & 5 & 5.7 & 5.4 & 0 & 0.0 \\
\hline 9 & 1037 & 1038 & 29.0 & 21.2 & 26 & 3.3 & 0 & 0.9 & 5.6 & 0 & 0 & 57.3 & 6.5 & 5.4 & 0 & 0 \\
\hline 10 & 473 & 473 & 29 & o1 & 2.6 & 3 & 0.0 & $0 \mathrm{c}$ & 5.6 & 11.9 & 57.0 & 57.3 & 65 & 5.4 & 0.0 & 0.0 \\
\hline 11 & 298 & 298 & 29.0 & 47 & 2.6 & 10.4 & 0.0 & 1.9 & 5.6 & 27.4 & 57.0 & 0 & 6.5 & 12.3 & 0.0 & 0.0 \\
\hline 12 & 298 & & & & 0.0 & 0.0 & 0 & 0.0 & 0 & 0.0 & 0.0 & 0.0 & 78.0 & .0 & 21.0 & 20 \\
\hline 13 & 3 & 308 & 0.0 & 0.0 & 0.0 & 0.0 & 0 & 0.0 & 0.0 & 0.0 & 0.0 & 0.0 & 0 & .0 & .0 & 20.0 \\
\hline 14 & 3 & 873 & 0.0 & 0.0 & 0 & 00 & 0.0 & 0.0 & 0.0 & 00 & 0.0 & .0 & 78.0 & 80.0 & 21.0 & 20.0 \\
\hline 15 & 1032 & 1023 & 0. & 0 & 0 & 0. & 0.0 & 0. & 0. & 0.0 & 0.0 & 0.0 & 90.0 & 81.0 & 9.2 & 19.0 \\
\hline 16 & 592 & 383 & 0.0 & 0.0 & 0.0 & 0.0 & 0.0 & 0.0 & 0.0 & 0.0 & 0.0 & 0.0 & 90.0 & 81.0 & 9.2 & 19.0 \\
\hline
\end{tabular}


Table 2. SOFC cell parameters and system operating conditions used as the model inputs.

\begin{tabular}{|c|c|c|}
\hline Parameter & \multicolumn{2}{|c|}{ Value } \\
\hline Main streams & \\
\hline Fuel flow rate, $\mathrm{kmol} / \mathrm{h}$ & \multicolumn{2}{|c|}{ Table 3} \\
\hline Fuel inlet pressure, atm & \multicolumn{2}{|c|}{1.0} \\
\hline Fuel composition, mole fraction & \multicolumn{2}{|c|}{ Table 3} \\
\hline Air flow rate, $\mathrm{kmol} / \mathrm{h}$ & \multicolumn{2}{|c|}{$8.8 \times 10^{-3}$} \\
\hline Air inlet pressure, atm & \multicolumn{2}{|c|}{1.0} \\
\hline \multicolumn{3}{|l|}{ Air composition, mole fraction } \\
\hline Nitrogen, $\mathrm{N}_{2}$ & \multicolumn{2}{|c|}{0.790} \\
\hline Oxygen, $\mathrm{O}_{2}$ & \multicolumn{2}{|c|}{0.210} \\
\hline \multicolumn{3}{|l|}{$\underline{\text { Reformer }}$} \\
\hline$\overline{\text { Reformer temperature, } \mathrm{K}}$ & \multicolumn{2}{|c|}{1073} \\
\hline Reformer pressure, atm & \multicolumn{2}{|c|}{1.0} \\
\hline \multicolumn{3}{|l|}{ Fuel cell stack } \\
\hline$\overline{\text { Number of cells }}$ & \multicolumn{2}{|c|}{4} \\
\hline Cell flow pattern & \multicolumn{2}{|c|}{ Co-flow } \\
\hline Cell voltage, $\mathrm{V}$ & \multicolumn{2}{|c|}{0.80} \\
\hline Pressure drop, atm & \multicolumn{2}{|c|}{0.05} \\
\hline SOFC cell specifications [17] & Cathode & Anode \\
\hline Catalyst thickness, $\mathrm{m}$ & $2.5 \times 10^{-4}$ & $3 \times 10^{-5}$ \\
\hline Porosity & 0.4 & 0.4 \\
\hline Anodic charge transfer coefficient & 2 & 1.4 \\
\hline Cathodic charge transfer coefficient & 1 & 0.6 \\
\hline Channel height, $\mathrm{m}$ & \multicolumn{2}{|c|}{$7.5 \times 10^{-4}$} \\
\hline Cell/channel length, $\mathrm{m}$ & \multicolumn{2}{|c|}{$1.0 \times 10^{-1}$} \\
\hline Electrolyte thickness, $\mathrm{m}$ & \multicolumn{2}{|c|}{$1.0 \times 10^{-5}$} \\
\hline
\end{tabular}


Table 3: Fuel specifications used in system simulation. All fuel flows are calibrated to give the same heating value inlet power.

\begin{tabular}{|c|c|c|c|}
\hline Fuel & $\begin{array}{c}\text { LHV } \\
(\mathrm{kJ} / \mathrm{mol} \\
\end{array}$ & $\begin{array}{l}\text { Flow rate } \\
\text { (kmol/hr) }\end{array}$ & $\begin{array}{c}\text { Composition (mol \%) } \\
{\left[\mathrm{CH}_{4}, \mathrm{C}_{2+}, \mathrm{H}_{2}, \mathrm{H}_{2} \mathrm{O}, \mathrm{CO}, \mathrm{CO}_{2}, \mathrm{~N}_{2,}\right]}\end{array}$ \\
\hline NG [1] & 799.76 & $4.05 \times 10^{-4}$ & {$[96.4,1.8,0.0,0.0,0.0,1.4,0.4]$} \\
\hline $\mathrm{BG}[1,22]$ & 481.78 & $6.72 \times 10^{-4}$ & {$[60.0,0.0,0.0,0.0,0.0,40.0,0.0]$} \\
\hline $\mathrm{SG}[1,23]$ & 217.24 & $1.49 \times 10^{-3}$ & {$[0.0,0.0,36.0,0.0,46.0,18.0,0.0]$} \\
\hline SF \#1 & 265.63 & $1.22 \times 10^{-3}$ & {$[8.0,0.2,33.0,0.0,42.1,16.5,0.2]$} \\
\hline SF \#2 & 341.73 & $9.48 \times 10^{-4}$ & {$[20.6,0.4,28.3,0.0,36.3,14.3,0.2]$} \\
\hline SF \#3 & 478.90 & $6.77 \times 10^{-4}$ & {$[43.3,0.8,19.8,0.0,25.5,10.0,0.6]$} \\
\hline \multicolumn{4}{|c|}{$\begin{array}{l}\text { SF \#1 }\left[\mathrm{y}_{N G}=0.25, \mathrm{y}_{S G}=0.75\right], \mathbf{S F} \# \mathbf{2}\left[\mathrm{y}_{N G}=0.50, \mathrm{y}_{S G}=0.50\right], \mathbf{S F} \# \mathbf{3}\left[\mathrm{y}_{N G}=0.75, \mathrm{y}_{S G}=0.25\right] \\
\mathrm{LHV}_{S F}=\mathrm{y}_{N G} \times \mathrm{LHV}_{N G}+\mathrm{y}_{S G} \times \operatorname{LHV}_{S G} ; \\
\text { y: mole fraction }\end{array}$} \\
\hline
\end{tabular}

Table 4: Simulation results.

\begin{tabular}{|c|c|c|c|c|c|c|c|}
\hline Fuel & $\begin{array}{c}\mathbf{i} \\
\left(\mathrm{A} / \mathbf{m}^{2}\right)\end{array}$ & $\begin{array}{c}\overline{\mathbf{T}} \\
(\mathbf{K})\end{array}$ & $\begin{array}{l}\Delta \mathbf{T} \\
(\mathbf{K})\end{array}$ & $\begin{array}{c}\text { Stack feed (reformate) composition } \\
\text { (mol\%) } \\
{\left[\mathrm{H}_{2}, \mathrm{H}_{2} \mathrm{O}, \mathrm{CO}, \mathrm{CO}_{2}, \mathrm{~N}_{2}\right]}\end{array}$ & $\begin{array}{r}\eta_{e l} \\
(\%)\end{array}$ & $\begin{array}{l}\eta_{t h} \\
\mathbf{( \% )}\end{array}$ & $\begin{array}{l}\eta^{\text {System }} \\
\text { (\%) }\end{array}$ \\
\hline $\mathrm{NG}$ & 1678 & 1219 & 121 & {$[67,7,23,3,0]$} & 62.7 & 22.4 & 85.1 \\
\hline $\mathrm{BG}$ & 1387 & 1216 & 113 & {$[51,13,28,8,0]$} & 51.8 & 28.9 & 80.7 \\
\hline SG & 770 & 1196 & 96 & {$[30,18,31,21,0]$} & 28.8 & 42.7 & 71.5 \\
\hline SF \#1 & 990 & 1203 & 102 & {$[37,17,30,16,0]$} & 37.0 & 37.8 & 74.8 \\
\hline $\mathrm{SF} \# 2$ & 1230 & 1210 & 108 & {$[45,15,29,10,1]$} & 45.9 & 32.5 & 78.4 \\
\hline SF \#3 & 1480 & 1218 & 114 & {$[55,12,27,6,0]$} & 55.3 & 26.8 & 82.1 \\
\hline
\end{tabular}


Table A1: Simulation results for NG fuelled system according to the flowsheet presented in Figure 2.

\begin{tabular}{|c|c|c|c|c|c|c|c|c|c|c|}
\hline \multirow{2}{*}{ Stream } & \multirow{2}{*}{$\begin{array}{c}\text { Temperature } \\
\text { (K) }\end{array}$} & \multirow{2}{*}{$\begin{array}{l}\text { Flowrate } \\
(\mathbf{k m o l} / \mathbf{h})\end{array}$} & \multicolumn{8}{|c|}{ Composition (mol \%) } \\
\hline & & & $\mathrm{CH}_{4}$ & $\mathbf{C}_{2+}$ & $\mathbf{H}_{2}$ & $\mathbf{H}_{2} \mathrm{O}$ & CO & $\mathrm{CO}_{2}$ & $\mathbf{N}_{2}$ & $\mathbf{O}_{2}$ \\
\hline 1 & 298 & $4.05 \times 10^{-4}$ & 96.4 & 1.8 & 0.0 & 0.0 & 0.0 & 1.4 & 0.4 & 0.0 \\
\hline 2 & 298 & $3.70 \times 10^{-4}$ & 0.0 & 0.0 & 0.0 & 100.0 & 0.0 & 0.0 & 0.0 & 0.0 \\
\hline 3 & 298 & $8.80 \times 10^{-3}$ & 0.0 & 0.0 & 0.0 & 0.0 & 0.0 & 0.0 & 79.0 & 21.0 \\
\hline 4 & 898 & $2.53 \times 10^{-3}$ & 17.1 & 0.3 & 37.0 & 28.2 & 15.3 & 1.8 & 0.3 & 0.0 \\
\hline 5 & 1073 & $3.16 \times 10^{-3}$ & 0.0 & 0.0 & 66.7 & 7.4 & 22.9 & 2.6 & 0.2 & 0.0 \\
\hline 6 & 1266 & $3.15 \times 10^{-3}$ & 0.0 & 0.0 & 55.2 & 18.9 & 22.9 & 2.6 & 0.2 & 0.0 \\
\hline 7 & 1266 & $1.58 \times 10^{-3}$ & 0.0 & 0.0 & 55.2 & 18.9 & 22.9 & 2.6 & 0.2 & 0.0 \\
\hline 8 & 1266 & $1.58 \times 10^{-3}$ & 0.0 & 0.0 & 55.2 & 18.9 & 22.9 & 2.6 & 0.2 & 0.0 \\
\hline 9 & 1850 & $1.42 \times 10^{-2}$ & 0.0 & 0.0 & 0.0 & 7.7 & 0.0 & 4.3 & 74.5 & 13.5 \\
\hline 10 & 1652 & $1.42 \times 10^{-2}$ & 0.0 & 0.0 & 0.0 & 7.7 & 0.0 & 4.3 & 74.5 & 13.5 \\
\hline 11 & 1020 & $1.42 \times 10^{-2}$ & 0.0 & 0.0 & 0.0 & 7.7 & 0.0 & 4.3 & 74.5 & 13.5 \\
\hline 12 & 1019 & $1.42 \times 10^{-2}$ & 0.0 & 0.0 & 0.0 & 7.7 & 0.0 & 4.3 & 74.5 & 13.5 \\
\hline 13 & 373 & $3.70 \times 10^{-4}$ & 0.0 & 0.0 & 0.0 & 100.0 & 0.0 & 0.0 & 0.0 & 0.0 \\
\hline 14 & 1073 & $8.80 \times 10^{-3}$ & 0.0 & 0.0 & 0.0 & 0.0 & 0.0 & 0.0 & 79.0 & 21.0 \\
\hline 15 & 1205 & $8.68 \times 10^{-3}$ & 0.0 & 0.0 & 0.0 & 0.0 & 0.0 & 0.0 & 81.5 & 18.5 \\
\hline
\end{tabular}


Table A2: Simulation results for BG fuelled system according to the flowsheet presented in Figure 2.

\begin{tabular}{|c|c|c|c|c|c|c|c|c|c|c|}
\hline \multirow{2}{*}{ Stream } & \multirow{2}{*}{$\begin{array}{c}\text { Temperature } \\
\text { (K) }\end{array}$} & \multirow{2}{*}{$\begin{array}{l}\text { Flowrate } \\
(\mathbf{k m o l} / \mathbf{h})\end{array}$} & \multicolumn{8}{|c|}{ Composition (mol \%) } \\
\hline & & & $\mathrm{CH}_{4}$ & $\mathbf{C}_{2+}$ & $\mathbf{H}_{2}$ & $\mathbf{H}_{2} \mathbf{O}$ & $\mathrm{CO}$ & $\mathrm{CO}_{2}$ & $\mathbf{N}_{2}$ & $\mathbf{O}_{2}$ \\
\hline 1 & 298 & $6.72 \times 10^{-4}$ & 60.0 & 0.0 & 0.0 & 0.0 & 0.0 & 40.0 & 0.0 & 0.0 \\
\hline 2 & 298 & $3.70 \times 10^{-4}$ & 0.0 & 0.0 & 0.0 & 100.0 & 0.0 & 0.0 & 0.0 & 0.0 \\
\hline 3 & 298 & $8.80 \times 10^{-3}$ & 0.0 & 0.0 & 0.0 & 0.0 & 0.0 & 0.0 & 79.0 & 21.0 \\
\hline 4 & 870 & $2.89 \times 10^{-3}$ & 13.9 & 0.0 & 26.1 & 28.1 & 17.4 & 14.6 & 0.0 & 0.0 \\
\hline 5 & 1073 & $3.68 \times 10^{-3}$ & 0.0 & 0.0 & 50.6 & 13.1 & 28.1 & 8.2 & 0.0 & 0.0 \\
\hline 6 & 1258 & $3.67 \times 10^{-3}$ & 0.0 & 0.0 & 41.1 & 22.9 & 27.4 & 8.6 & 0.0 & 0.0 \\
\hline 7 & 1258 & $1.84 \times 10^{-3}$ & 0.0 & 0.0 & 41.1 & 22.9 & 27.4 & 8.6 & 0.0 & 0.0 \\
\hline 8 & 1258 & $1.84 \times 10^{-3}$ & 0.0 & 0.0 & 41.1 & 22.9 & 27.4 & 8.6 & 0.0 & 0.0 \\
\hline 9 & 1821 & $1.42 \times 10^{-2}$ & 0.0 & 0.0 & 0.0 & 7.7 & 0.0 & 4.5 & 74.4 & 13.4 \\
\hline 10 & 1655 & $1.42 \times 10^{-2}$ & 0.0 & 0.0 & 0.0 & 7.7 & 0.0 & 4.5 & 74.4 & 13.4 \\
\hline 11 & 1027 & $1.42 \times 10^{-2}$ & 0.0 & 0.0 & 0.0 & 7.7 & 0.0 & 4.5 & 74.4 & 13.4 \\
\hline 12 & 1026 & $1.42 \times 10^{-2}$ & 0.0 & 0.0 & 0.0 & 7.7 & 0.0 & 4.5 & 74.4 & 13.4 \\
\hline 13 & 373 & $3.70 \times 10^{-4}$ & 0.0 & 0.0 & 0.0 & 100.0 & 0.0 & 0.0 & 0.0 & 0.0 \\
\hline 14 & 1073 & $8.80 \times 10^{-3}$ & 0.0 & 0.0 & 0.0 & 0.0 & 0.0 & 0.0 & 79.0 & 21.0 \\
\hline 15 & 1197 & $8.70 \times 10^{-3}$ & 0.0 & 0.0 & 0.0 & 0.0 & 0.0 & 0.0 & 81.0 & 19.0 \\
\hline
\end{tabular}


Table A3: Simulation results for SG fuelled system according to the flowsheet presented in Figure 2.

\begin{tabular}{|c|c|c|c|c|c|c|c|c|c|c|}
\hline \multirow{2}{*}{ Stream } & \multirow{2}{*}{$\begin{array}{c}\text { Temperature } \\
\text { (K) }\end{array}$} & \multirow{2}{*}{$\begin{array}{l}\text { Flowrate } \\
(\mathbf{k m o l} / \mathbf{h})\end{array}$} & \multicolumn{8}{|c|}{ Composition (mol \%) } \\
\hline & & & $\mathrm{CH}_{4}$ & $\mathbf{C}_{2+}$ & $\mathbf{H}_{2}$ & $\mathrm{H}_{2} \mathrm{O}$ & CO & $\mathrm{CO}_{2}$ & $\mathbf{N}_{2}$ & $\mathrm{O}_{2}$ \\
\hline 1 & 298 & $1.49 \times 10^{-3}$ & 0.0 & 0.0 & 36.0 & 0.0 & 46.0 & 18.0 & 0.0 & 0.0 \\
\hline 2 & 298 & $3.70 \times 10^{-4}$ & 0.0 & 0.0 & 0 & 100.0 & 0.0 & 0.0 & 0.0 & 0.0 \\
\hline 3 & 298 & $8.80 \times 10^{-3}$ & 0.0 & 0.0 & 0.0 & 0.0 & 0.0 & 0.0 & 79.0 & 21.0 \\
\hline 4 & 812 & $3.72 \times 10^{-3}$ & 0.0 & 0.0 & 27.3 & 21.4 & 33.8 & 17.4 & 0.0 & 0.0 \\
\hline 5 & 1073 & $3.72 \times 10^{-3}$ & 0.0 & 0.0 & 30.3 & 18.4 & 30.9 & 20.4 & 0.0 & 0.0 \\
\hline 6 & 1236 & $3.71 \times 10^{-3}$ & 0.0 & 0.0 & 25.7 & 23.0 & 30.9 & 20.4 & 0.0 & 0.0 \\
\hline 7 & 1236 & $1.86 \times 10^{-3}$ & 0.0 & 0.0 & 25.7 & 23.0 & 30.9 & 20.4 & 0.0 & 0.0 \\
\hline 8 & 1236 & $1.86 \times 10^{-3}$ & 0.0 & 0.0 & 25.7 & 23.0 & 30.9 & 20.4 & 0.0 & 0.0 \\
\hline 9 & 1715 & $1.46 \times 10^{-2}$ & 0.0 & 0.0 & 0.0 & 6.1 & 0.0 & 6.5 & 73.2 & 14.2 \\
\hline 10 & 1657 & $1.46 \times 10^{-2}$ & 0.0 & 0.0 & 0.0 & 6.1 & 0.0 & 6.5 & 73.2 & 14.2 \\
\hline 11 & 1056 & $1.46 \times 10^{-2}$ & 0.0 & 0.0 & 0.0 & 6.1 & 0.0 & 6.5 & 73.2 & 14.2 \\
\hline 12 & 1054 & $1.46 \times 10^{-2}$ & 0.0 & 0.0 & 0.0 & 6.1 & 0.0 & 6.5 & 73.2 & 14.2 \\
\hline 13 & 373 & $3.70 \times 10^{-4}$ & 0.0 & 0.0 & 0.0 & 100.0 & 0.0 & 0.0 & 0.0 & 0.0 \\
\hline 14 & 1073 & $8.80 \times 10^{-3}$ & 0.0 & 0.0 & 0.0 & 0.0 & 0.0 & 0.0 & 79.0 & 21.0 \\
\hline 15 & 1196 & $8.75 \times 10^{-3}$ & 0.0 & 0.0 & 0.0 & 0.0 & 0.0 & 0.0 & 80.6 & 19.4 \\
\hline
\end{tabular}


Table A4: Simulation results for SF\#1 fuelled system according to the flowsheet presented in Figure 2.

\begin{tabular}{|c|c|c|c|c|c|c|c|c|c|c|}
\hline \multirow{2}{*}{ Stream } & \multirow{2}{*}{$\begin{array}{c}\text { Temperature } \\
\text { (K) }\end{array}$} & \multirow{2}{*}{$\begin{array}{l}\text { Flowrate } \\
(\mathbf{k m o l} / \mathbf{h})\end{array}$} & \multicolumn{8}{|c|}{ Composition (mol \%) } \\
\hline & & & $\mathrm{CH}_{4}$ & $\mathbf{C}_{2+}$ & $\mathbf{H}_{2}$ & $\mathrm{H}_{2} \mathrm{O}$ & CO & $\mathrm{CO}_{2}$ & $\mathbf{N}_{2}$ & $\mathbf{O}_{2}$ \\
\hline 1 & 298 & $1.22 \times 10^{-3}$ & 8.0 & 0.2 & 33.0 & 0.0 & 42.1 & 16.5 & 0.2 & 0.0 \\
\hline 2 & 298 & $3.70 \times 10^{-4}$ & 0.0 & 0.0 & 0.0 & 100.0 & 0.0 & 0.0 & 0.0 & 0.0 \\
\hline 3 & 298 & $8.80 \times 10^{-3}$ & 0.0 & 0.0 & 0.0 & 0.0 & 0.0 & 0.0 & 79.0 & 21.0 \\
\hline 4 & 830 & $3.38 \times 10^{-3}$ & 2.9 & 0.0 & 28.5 & 23.2 & 31.3 & 14.0 & 0.1 & 0.0 \\
\hline 5 & 1073 & $3.59 \times 10^{-3}$ & 0.0 & 0.0 & 37.2 & 16.9 & 30.4 & 15.5 & 0.0 & 0.0 \\
\hline 6 & 1245 & $3.58 \times 10^{-3}$ & 0.0 & 0.0 & 31.2 & 23.0 & 30.4 & 15.3 & 0.0 & 0.0 \\
\hline 7 & 1245 & $1.79 \times 10^{-3}$ & 0.0 & 0.0 & 31.2 & 23.0 & 30.4 & 15.3 & 0.0 & 0.0 \\
\hline 8 & 1245 & $1.79 \times 10^{-3}$ & 0.0 & 0.0 & 31.2 & 23.0 & 30.4 & 15.3 & 0.0 & 0.0 \\
\hline 9 & 1751 & $1.44 \times 10^{-2}$ & 0.0 & 0.0 & 0.0 & 6.7 & 0.0 & 5.6 & 73.8 & 13.9 \\
\hline 10 & 1658 & $1.44 \times 10^{-2}$ & 0.0 & 0.0 & 0.0 & 6.7 & 0.0 & 5.6 & 73.8 & 13.9 \\
\hline 11 & 1050 & $1.44 \times 10^{-2}$ & 0.0 & 0.0 & 0.0 & 6.7 & 0.0 & 5.6 & 73.8 & 13.9 \\
\hline 12 & 1049 & $1.44 \times 10^{-2}$ & 0.0 & 0.0 & 0.0 & 6.7 & 0.0 & 5.6 & 73.8 & 13.9 \\
\hline 13 & 373 & $3.7 \times 10^{-4}$ & 0.0 & 0.0 & 0.0 & 100.0 & 0.0 & 0.0 & 0.0 & 0.0 \\
\hline 14 & 1073 & $8.80 \times 10^{-3}$ & 0.0 & 0.0 & 0.0 & 0.0 & 0.0 & 0.0 & 79.0 & 21.0 \\
\hline 15 & 1204 & $8.73 \times 10^{-3}$ & 0.0 & 0.0 & 0.0 & 0.0 & 0.0 & 0.0 & 80.8 & 19.2 \\
\hline
\end{tabular}


Table A5: Simulation results for SF\#2 fuelled system according to the flowsheet presented in Figure 2.

\begin{tabular}{|c|c|c|c|c|c|c|c|c|c|c|}
\hline \multirow{2}{*}{ Stream } & \multirow{2}{*}{$\begin{array}{c}\text { Temperature } \\
\text { (K) }\end{array}$} & \multirow{2}{*}{$\begin{array}{l}\text { Flowrate } \\
\text { (kmol/h) }\end{array}$} & \multicolumn{8}{|c|}{ Composition (mol \%) } \\
\hline & & & $\mathrm{CH}_{4}$ & $\mathbf{C}_{2+}$ & $\mathbf{H}_{2}$ & $\mathrm{H}_{2} \mathrm{O}$ & CO & $\mathrm{CO}_{2}$ & $\mathbf{N}_{2}$ & $\mathbf{O}_{2}$ \\
\hline 1 & 298 & $9.48 \times 10^{-3}$ & 20.6 & 0.4 & 28.3 & 0.0 & 36.3 & 14.3 & 0.2 & 0.0 \\
\hline 2 & 298 & $3.70 \times 10^{-4}$ & 0.0 & 0.0 & 0.0 & 100.0 & 0.0 & 0.0 & 0.0 & 0.0 \\
\hline 3 & 298 & $8.80 \times 10^{-3}$ & 0.0 & 0.0 & 0.0 & 0.0 & 0.0 & 0.0 & 79.0 & 21.0 \\
\hline 4 & 850 & $3.04 \times 10^{-3}$ & 6.5 & 0.1 & 30.1 & 25.1 & 27.7 & 10.4 & 0.2 & 0.0 \\
\hline 5 & 1073 & $3.44 \times 10^{-3}$ & 0.0 & 0.0 & 45.3 & 15.0 & 29.1 & 10.4 & 0.2 & 0.0 \\
\hline 6 & 1253 & $3.43 \times 10^{-3}$ & 0.0 & 0.0 & 37.5 & 22.8 & 29.0 & 10.5 & 0.2 & 0.0 \\
\hline 7 & 1253 & $1.72 \times 10^{-3}$ & 0.0 & 0.0 & 37.5 & 22.8 & 29.0 & 10.5 & 0.2 & 0.0 \\
\hline 8 & 1253 & $1.72 \times 10^{-3}$ & 0.0 & 0.0 & 37.5 & 22.8 & 29.0 & 10.5 & 0.2 & 0.0 \\
\hline 9 & 1782 & $1.43 \times 10^{-3}$ & 0.0 & 0.0 & 0.0 & 7.2 & 0.0 & 4.7 & 74.4 & 13.7 \\
\hline 10 & 1656 & $1.43 \times 10^{-3}$ & 0.0 & 0.0 & 0.0 & 7.2 & 0.0 & 4.7 & 74.4 & 13.7 \\
\hline 11 & 1039 & $1.43 \times 10^{-3}$ & 0.0 & 0.0 & 0.0 & 7.2 & 0.0 & 4.7 & 74.4 & 13.7 \\
\hline 12 & 1038 & $1.43 \times 10^{-3}$ & 0.0 & 0.0 & 0.0 & 7.2 & 0.0 & 4.7 & 74.4 & 13.7 \\
\hline 13 & 373 & $3.70 \times 10^{-4}$ & 0.0 & 0.0 & 0.0 & 100.0 & 0.0 & 0.0 & 0.0 & 0.0 \\
\hline 14 & 1073 & $8.80 \times 10^{-3}$ & 0.0 & 0.0 & 0.0 & 0.0 & 0.0 & 0.0 & 79.0 & 21.0 \\
\hline 15 & 1212 & $8.71 \times 10^{-3}$ & 0.0 & 0.0 & 0.0 & 0.0 & 0.0 & 0.0 & 80.9 & 19.1 \\
\hline
\end{tabular}


Table A6: Simulation results for SF\#3 fuelled system according to the flowsheet presented in Figure 2.

\begin{tabular}{|c|c|c|c|c|c|c|c|c|c|c|}
\hline \multirow{2}{*}{ Stream } & \multirow{2}{*}{$\begin{array}{c}\text { Temperature } \\
\text { (K) }\end{array}$} & \multirow{2}{*}{$\begin{array}{l}\text { Flowrate } \\
(\mathbf{k m o l} / \mathbf{h})\end{array}$} & \multicolumn{8}{|c|}{ Composition (mol \%) } \\
\hline & & & $\mathrm{CH}_{4}$ & $\mathrm{C}_{2+}$ & $\mathbf{H}_{2}$ & $\mathrm{H}_{2} \mathrm{O}$ & CO & $\mathrm{CO}_{2}$ & $\mathbf{N}_{2}$ & $\mathbf{O}_{2}$ \\
\hline 1 & 298 & $6.77 \times 10^{-4}$ & 43.3 & 0.8 & 19.8 & 0.0 & 25.5 & 10.0 & 0.6 & 0.0 \\
\hline 2 & 298 & $3.70 \times 10^{-4}$ & 0.0 & 0.0 & 0.0 & 100.0 & 0.0 & 0.0 & 0.0 & 0.0 \\
\hline 3 & 298 & $8.80 \times 10^{-3}$ & 0.0 & 0.0 & 0.0 & 0.0 & 0.0 & 0.0 & 79.0 & 21.0 \\
\hline 4 & 872 & $2.70 \times 10^{-3}$ & 11.0 & 0.2 & 32.6 & 26.9 & 22.7 & 6.3 & 0.2 & 0.0 \\
\hline 5 & 1073 & $3.31 \times 10^{-3}$ & 0.0 & 0.0 & 55.1 & 11.7 & 26.8 & 6.2 & 0.2 & 0.0 \\
\hline 6 & 1262 & $3.30 \times 10^{-3}$ & 0.0 & 0.0 & 45.2 & 21.5 & 26.8 & 6.2 & 0.1 & 0.0 \\
\hline 7 & 1262 & $1.65 \times 10^{-3}$ & 0.0 & 0.0 & 45.2 & 21.5 & 26.8 & 6.2 & 0.1 & 0.0 \\
\hline 8 & 1262 & $1.65 \times 10^{-3}$ & 0.0 & 0.0 & 45.2 & 21.5 & 26.8 & 6.2 & 0.1 & 0.0 \\
\hline 9 & 1813 & $1.42 \times 10^{-2}$ & 0.0 & 0.0 & 0.0 & 7.7 & 0.0 & 3.8 & 75.0 & 13.5 \\
\hline 10 & 1650 & $1.42 \times 10^{-2}$ & 0.0 & 0.0 & 0.0 & 7.7 & 0.0 & 3.8 & 75.0 & 13.5 \\
\hline 11 & 1024 & $1.42 \times 10^{-2}$ & 0.0 & 0.0 & 0.0 & 7.7 & 0.0 & 3.8 & 75.0 & 13.5 \\
\hline 12 & 1023 & $1.42 \times 10^{-2}$ & 0.0 & 0.0 & 0.0 & 7.7 & 0.0 & 3.8 & 75.0 & 13.5 \\
\hline 13 & 373 & $3.70 \times 10^{-4}$ & 0.0 & 0.0 & 0.0 & 100.0 & 0.0 & 0.0 & 0.0 & 0.0 \\
\hline 14 & 1073 & $8.80 \times 10^{-3}$ & 0.0 & 0.0 & 0.0 & 0.0 & 0.0 & 0.0 & 79.0 & 21.0 \\
\hline 15 & 1219 & $8.70 \times 10^{-3}$ & 0.0 & 0.0 & 0.0 & 0.0 & 0.0 & 0.0 & 81.1 & 18.9 \\
\hline
\end{tabular}



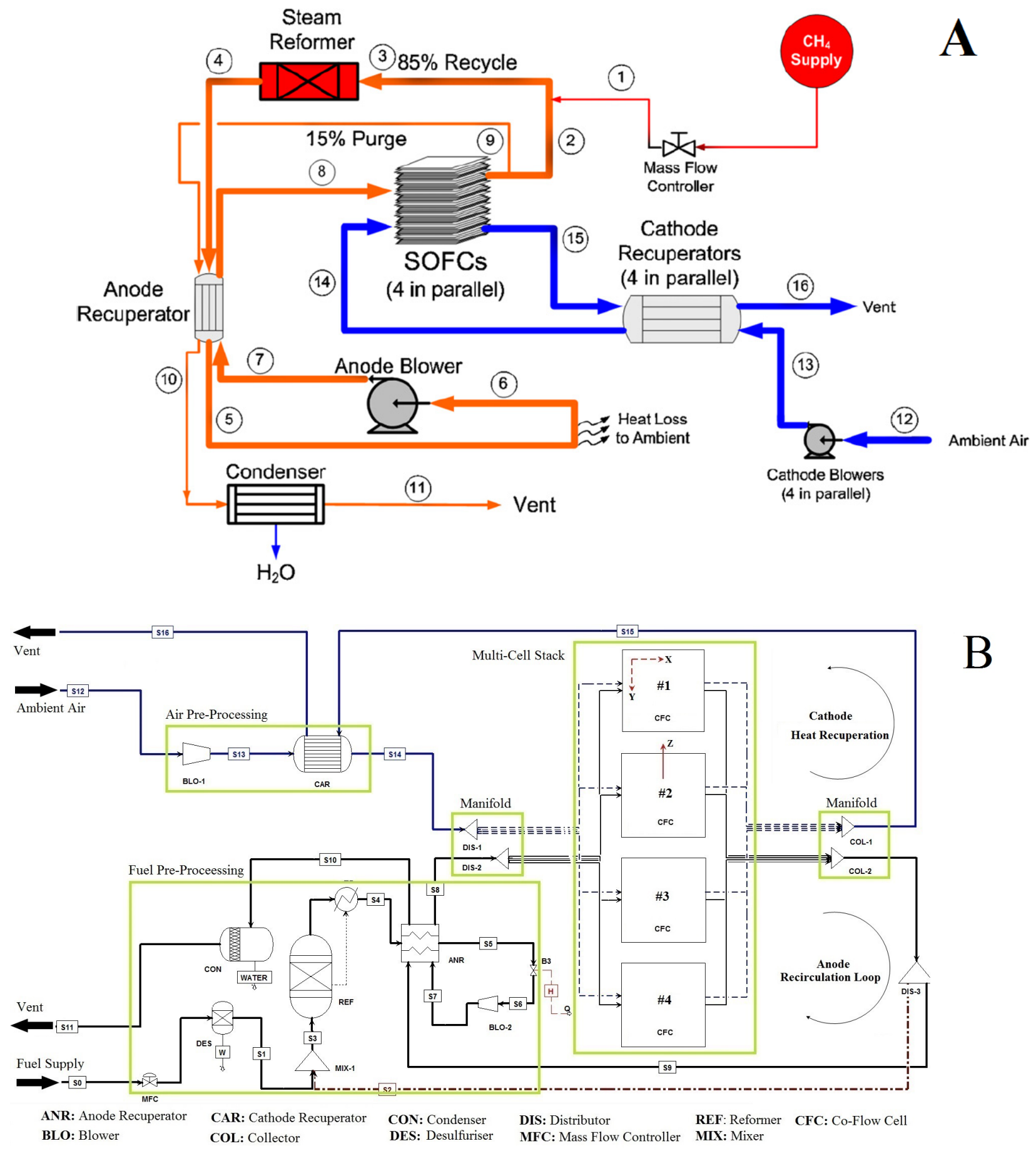

B

Figure 1: (A) Test rig flowsheet used with permission [16]; (B) Process flow diagram developed in this work to simulate the test rig flowsheet. The streams marked with ' $S$ ' are those monitored, modelled and compared in Table 1. 


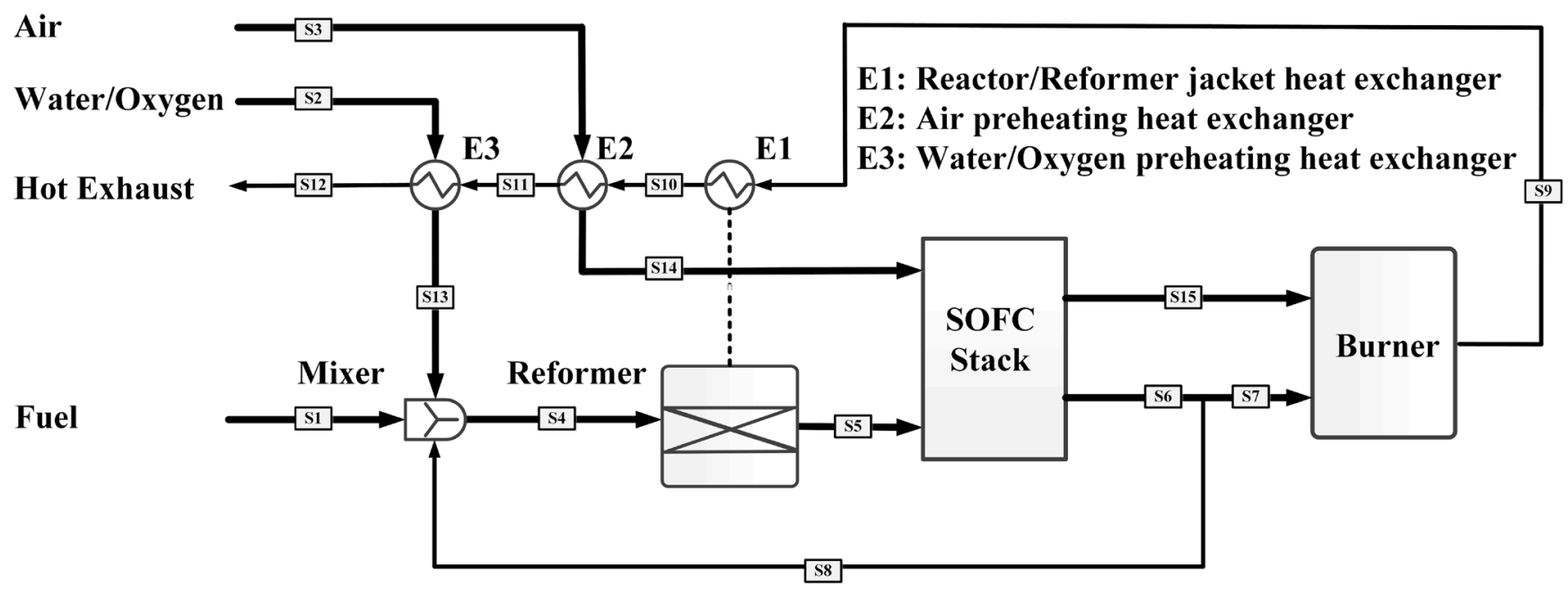

Figure 2: Process flow diagram involving anode off gas recycling, depleted fuel combustion and partial heat recovery units. 

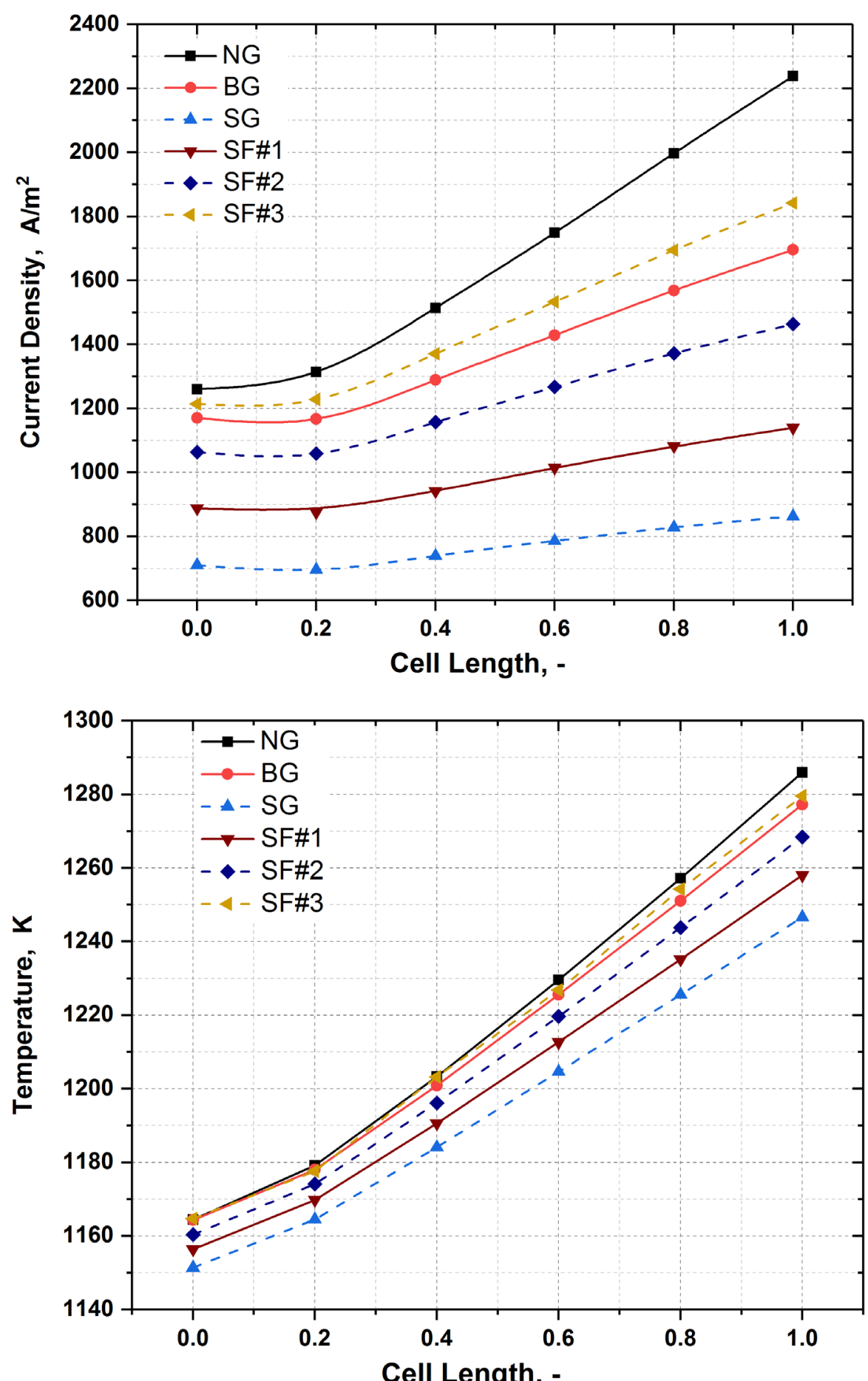

Figure 3: Current density and temperature variations along the cell/stack normalised length, $\mathbf{x} / \mathbf{L}^{\text {Cell }}$, for various fuels. 

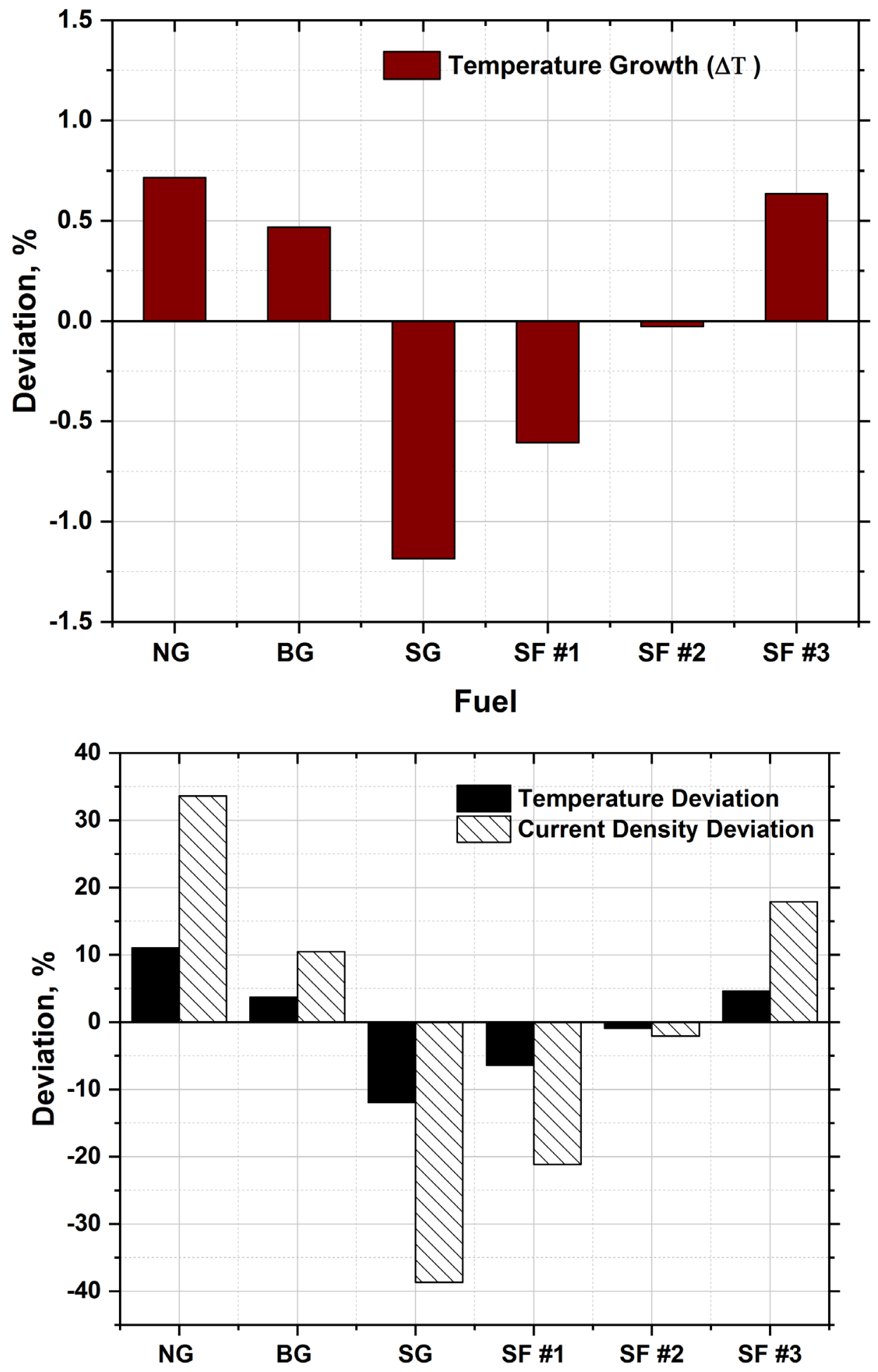

Fuel

Figure 4: Deviation factor for current, teperature and teperature gradiant inside the stack while applying various fuels. 

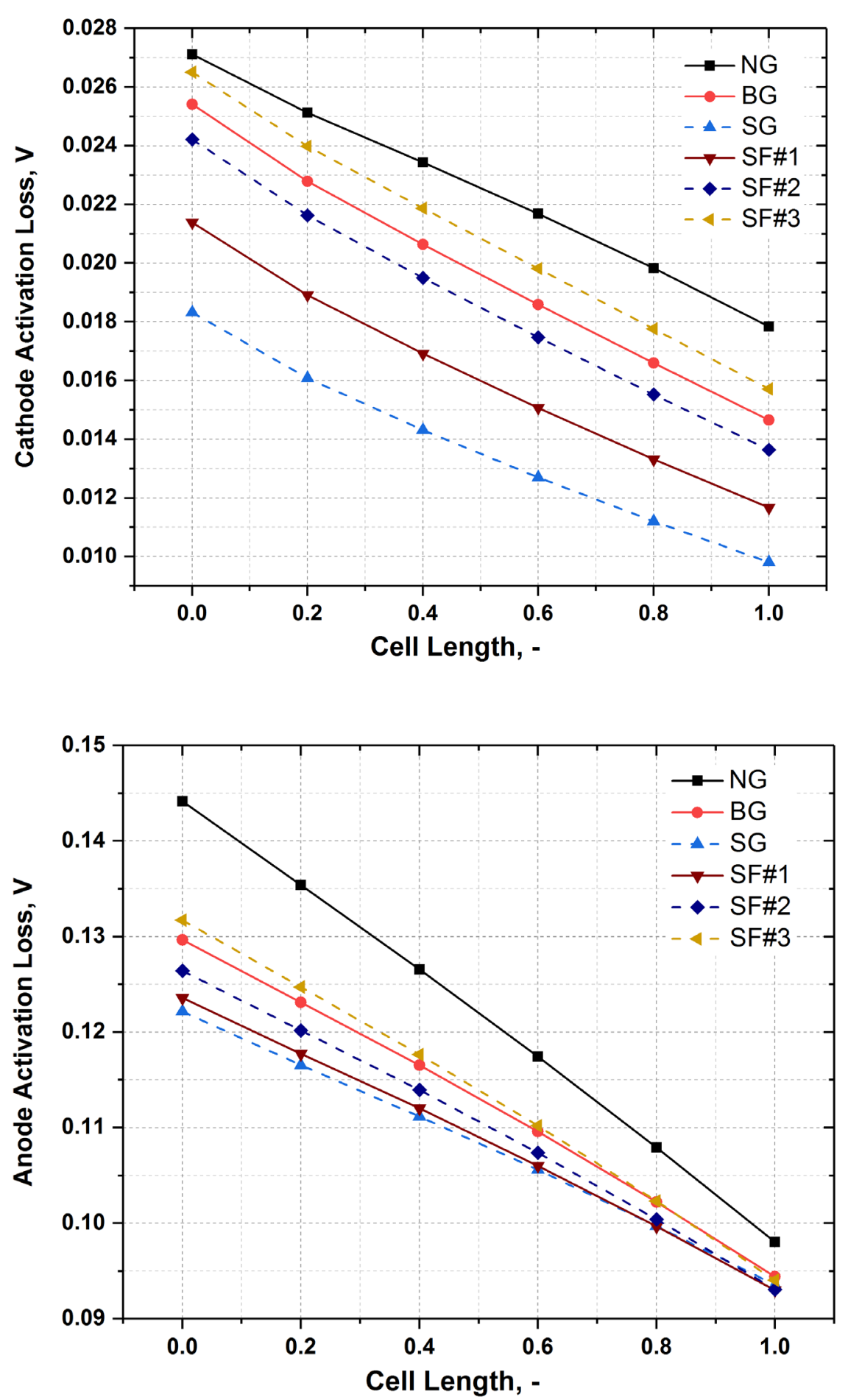

Figure 5: Local OCV and voltage loss elements along the cell/stack normalised length, $x / L^{\text {Cell }}$, for various fuel for assumed constant operating voltage, $0.80 \mathrm{~V}$, justifiable considering the metallic interconnect. 

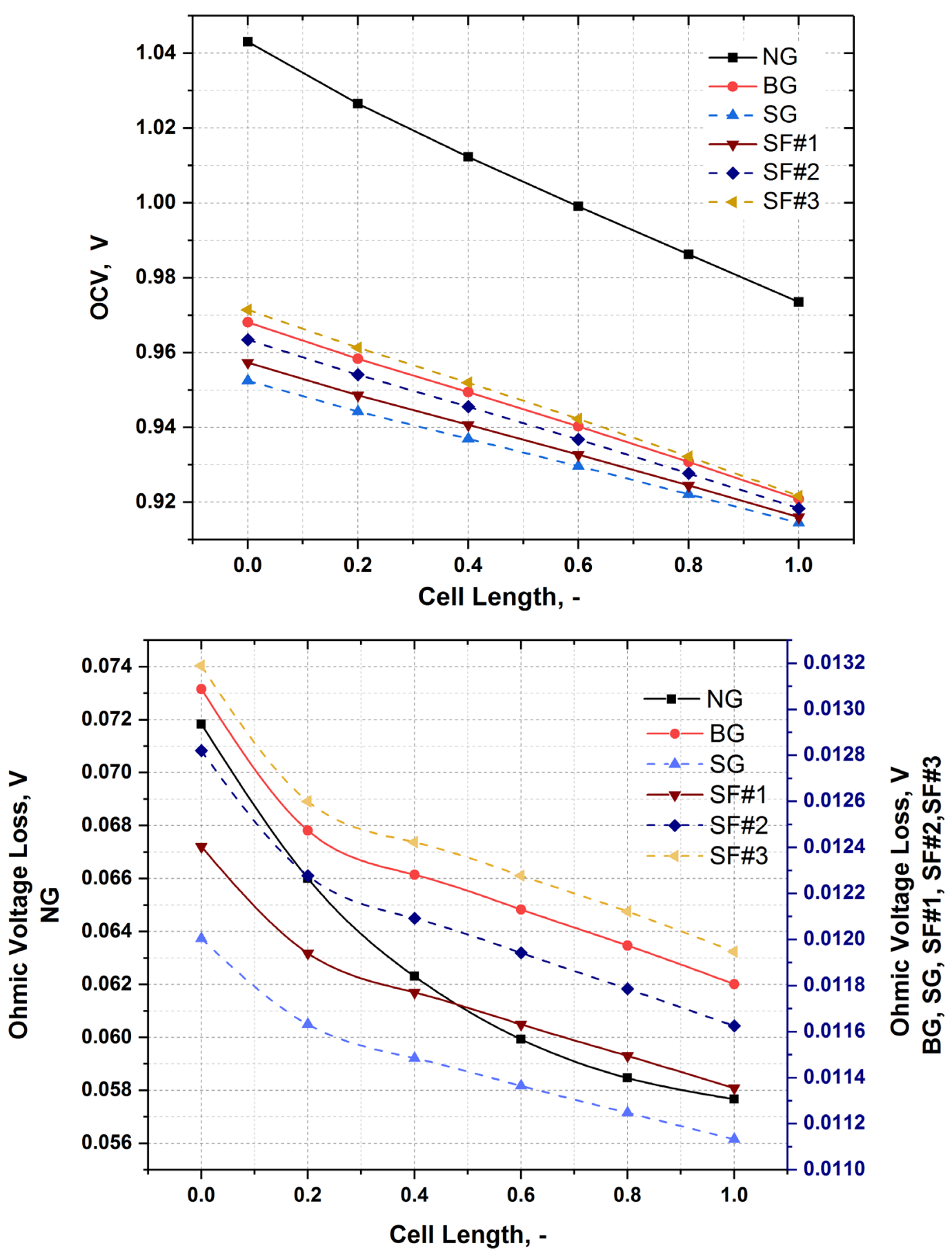

Figure 5 (cont.): Local OCV and voltage loss elements along the cell/stack normalised length, $\mathbf{x} / \mathbf{L}^{\text {Cell }}$, for various fuel. 


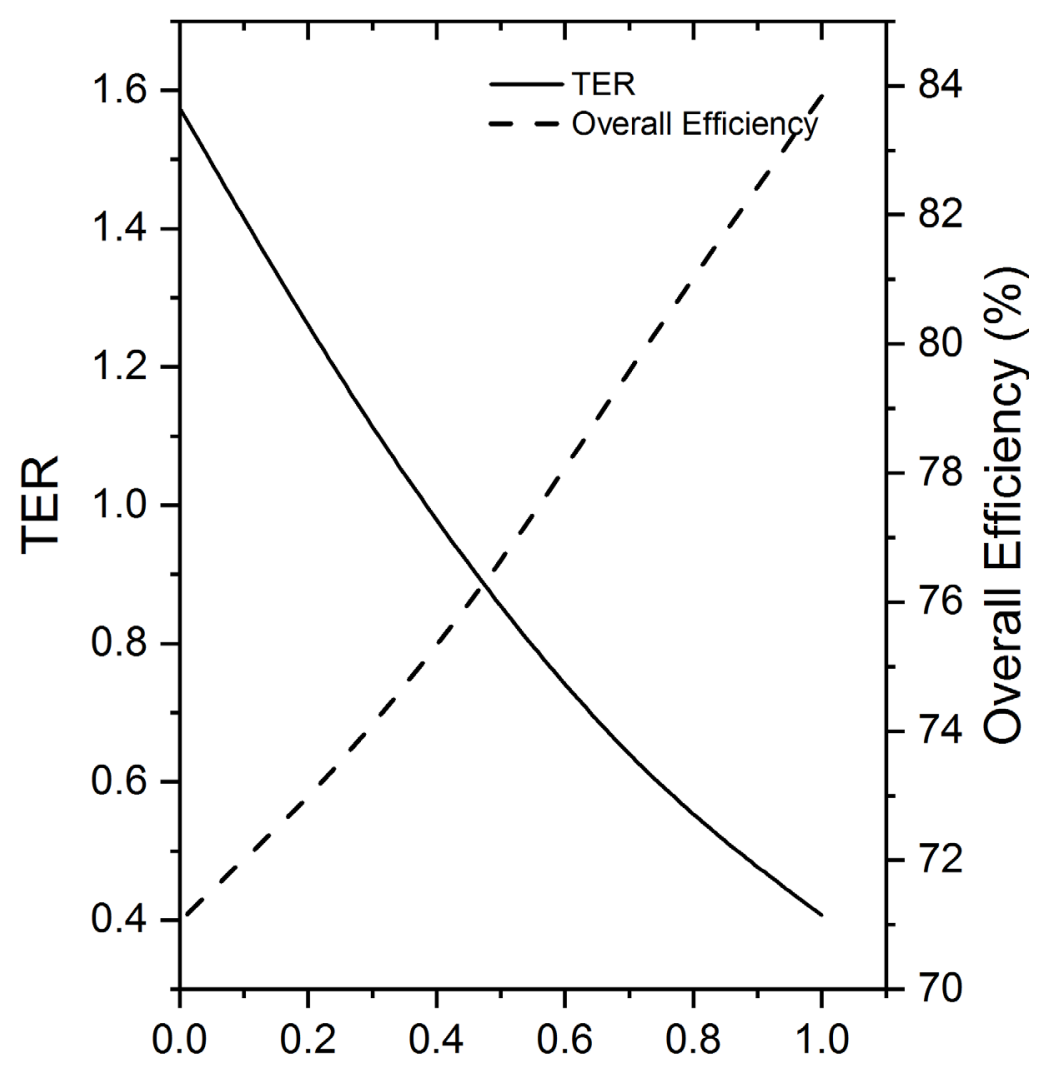

Fuel Mixture NG Fraction

Figure 6: System TER $\left(\mathrm{W}_{\mathrm{th}} / \mathrm{W}_{\mathrm{el}}\right)$ and overall efficiency for fuel mixtures (NG+SG). 

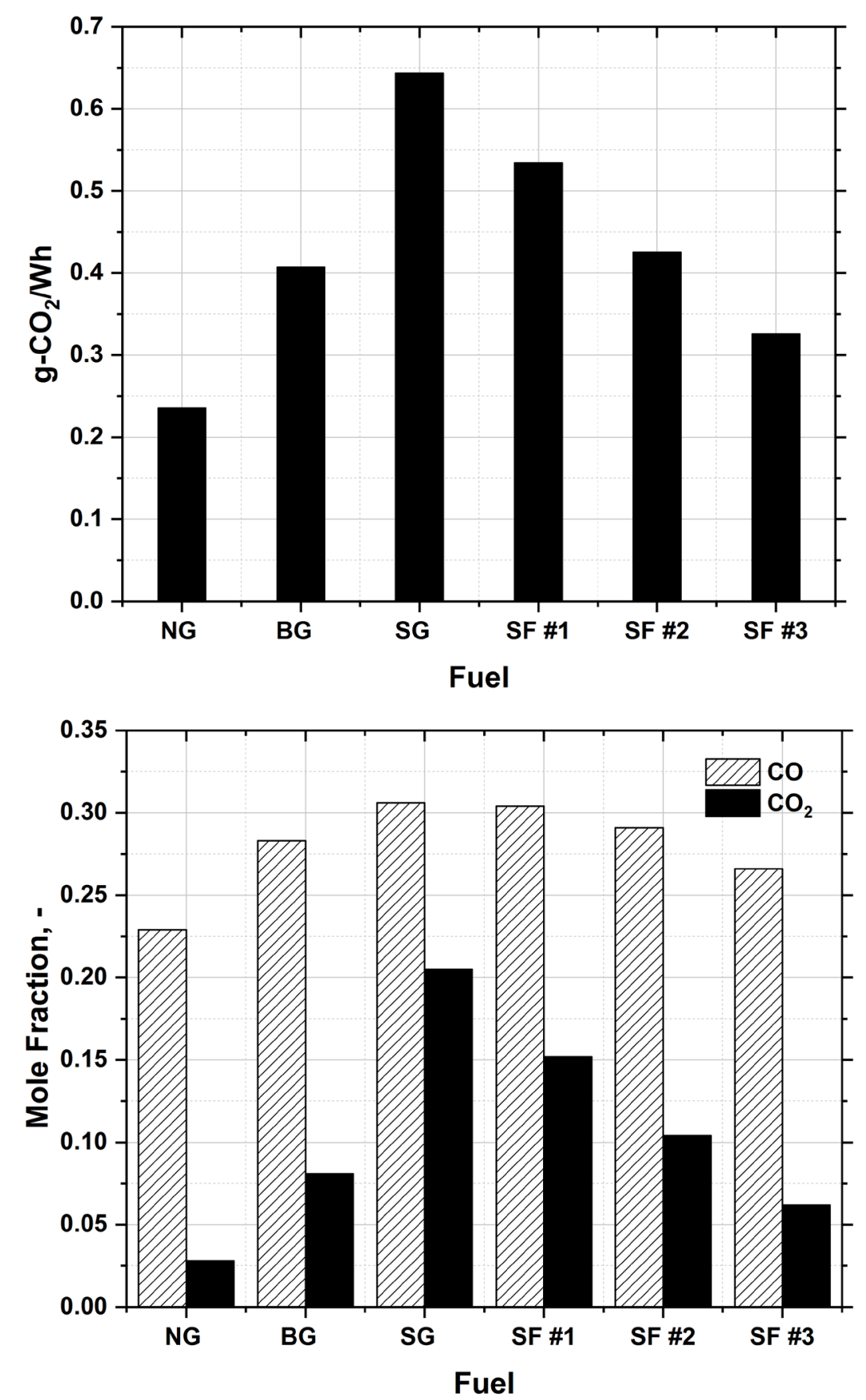

Figure 7: $\mathrm{CO}_{\mathrm{x}}$ mole fractions in stack outlet and system specific greenhouse gas (GHG) release $\left(\mathrm{g}-\mathrm{CO}_{\mathrm{x}} / \mathrm{Wh}\right)$ for various fuel mixtures. 
